\title{
THE BARIUM SALTS OF PHTHALIC ACID.
}

By F. B. AlLAN.

Received July Iz, Igog.

Carius ${ }^{2}$ described the neutral barium phthalate $\mathrm{C}_{6} \mathrm{H}_{4} \mathrm{C}_{2} \mathrm{O}_{4} \mathrm{Ba}$, the acid phthalate $\left(\mathrm{C}_{6} \mathrm{H}_{4} \mathrm{C}_{2} \mathrm{O}_{4}\right)_{2} \mathrm{H}_{2} \mathrm{Ba}$, and a basic phthalate to which he was unable to give a formula, but his analyses were not far from $\left(\mathrm{C}_{6} \mathrm{H}_{4} \mathrm{C}_{2} \mathrm{O}_{4} \mathrm{Ba}\right)_{3} \mathrm{BaO}$. $\mathrm{He}$ also found that if the preparation was made by adding hot baryta solution to the hot phthalic acid solution, a product of variable composition was obtained but that very frequently this contained about 42 per cent. of barium, nearly $\left(\mathrm{C}_{6} \mathrm{H}_{4} \mathrm{C}_{2} \mathrm{O}_{4}\right)_{2} \mathrm{H}_{2} \mathrm{Ba}\left(\mathrm{C}_{6} \mathrm{H}_{4} \mathrm{C}_{2} \mathrm{O}_{4} \mathrm{Ba}\right)_{6}$. Hermann ${ }^{3}$ evaporated a solution of phthalic acid, neutralized by baryta, and obtained a barium salt in the form of fine needles which gave as the average of three analyses 41.04 per cent. barium, and he gives it the formula $\left(\mathrm{C}_{6} \mathrm{H}_{4} \mathrm{C}_{2} \mathrm{O}_{4}\right)_{8} \mathrm{H}_{2} \mathrm{Ba}_{3}$. He mentions that on heating the acid barium phthalate $\left(\mathrm{C}_{6} \mathrm{H}_{4} \mathrm{C}_{2} \mathrm{O}_{4}\right)_{2} \mathrm{H}_{2} \mathrm{Ba}$ to ${ }_{5} 0^{\circ}$, it lost much phthalic acid and the residue had nearly the same composition as his first mentioned salt. Weith ${ }^{4}$ added barium chloride solution to a solution of ammonium phthalate, dissolved the precipitate in water and evaporated the solution, obtaining a salt containing 4 I.2 per cent. barium.

Miller and Kenrick ${ }^{5}$ have shown how the Phase Rule can be applied to the identification of basic salts and the author ${ }^{6}$ has used it for the identification of basic and acid salts. In this case, the Phase Rule has been applied to a system containing the components of phthalic acid, barium hydroxide and water. The phthalic acid and barium hydroxide were shaken with water at room temperature and in most cases equilibrium was reached in a few hours, but in some cases it was not reached when the bottles had been shaken for weeks.

The accompanying table gives the quantities of phthalic acid, barium hydroxide $\mathrm{Ba}(\mathrm{OH})_{2} \mathrm{SH}_{2} \mathrm{O}$, and water used in each bottle, and the analysis of the solution at equilibrium. It will be observed that the proportion of water and phthalic acid in the various bottles is constant with one exception. This made it much easier to make up new bottles to fill any gaps in the table because since the solubility of the salts was not known it would not have been possible otherwise to foretell the composition of the precipitate. Most of the bottles were stirred much longer than was necessary, as they were left in the stirrer till it was convenient

${ }^{1}$ Read at Detroit meeting of American Chemical Society.

${ }^{2}$ Ann., 148, 64 .

${ }^{3} A$ Ann., I5 58 .

- Ber., 7, 1059.

- Trans. Roy. Soc. Can., I901.

- Amer. Chem. J., 25, 307; 27, 284. This Journal, 25, 722, Trans. Roy. Soc. Can., 1903. 
to make an analysis, but in the case of Nos. I I to I3, equilibrium had not been reached in sixty days.

\begin{tabular}{|c|c|c|c|c|c|c|}
\hline No. & $\begin{array}{l}\text { Acid. } \\
\text { Grams }\end{array}$ & $\begin{array}{l}\text { Batiun } \\
\text { hydroxide. } \\
\text { Grams. }\end{array}$ & $\begin{array}{l}\text { Water. } \\
\text { Grams. }\end{array}$ & $\begin{array}{c}\text { Solution. } \\
\mathrm{N} \text { acid. }\end{array}$ & $\begin{array}{l}\text { Time stir } \\
\text { Days. }\end{array}$ & red. \\
\hline I & 5.0 & 1.0 & 100 & 0.09 .56 & 4 & \\
\hline 2 & 2.5 & I.O & 100 & 0.0953 & 4 & \\
\hline 3 & 2.5 & I. 5 & 100 & 0.0953 & 4 & \\
\hline 4 & 2.5 & $I .75$ & 100 & 0.0946 & 4 & \\
\hline 5 & 2.5 & 2.0 & 100 & 0.0817 & 4 & \\
\hline 6 & $2 \cdot 5$ & 2.25 & 100 & 0.0483 & 4 & \\
\hline 7 & $2 \cdot 5$ & 2.5 & 100 & 0.0377 & 4 & \\
\hline 8 & 2.5 & 3.0 & 100 & 0.0376 & 4 & \\
\hline 9 & $2 \cdot 5$ & 3.25 & 100 & 0.0374 & 4 & \\
\hline IO & 2.5 & $3 \cdot 5$ & 100 & 0.0375 & 4 & \\
\hline I I & $2 \cdot 5$ & $3 \cdot 75$ & 100 & 0.0083 & 60 & equilibrium \\
\hline I 2 & $2 \cdot 5$ & 4.0 & IOO & 0.0061 & 60 & not \\
\hline 13 & 2.5 & $4 \cdot 25$ & 100 & 0.0032 & 60 & reached \\
\hline I4 & $2 \cdot 5$ & $4 \cdot 5$ & 100 & neutral & 4 & \\
\hline I 5 & 2.5 & $4 \cdot 75$ & 100 & $\begin{array}{c}\text { neutral } \\
\text { basic }\end{array}$ & 4 & \\
\hline I6 & 1.0 & 2.2 & 40 & 0.0352 & I & \\
\hline 17 & I. $O$ & 2.5 & 40 & 0.0883 & $I$ & \\
\hline 18 & 1.0 & 2.8 & 40 & 0.135 & $I$ & \\
\hline I9 & 1.0 & $3 \cdot 2$ & 40 & 0.188 & $2 I$ & \\
\hline 20 & 1.0 & $3 \cdot 3$ & 40 & 0.200 & $2 \mathrm{I}$ & \\
\hline 2 I & 1.0 & $3 \cdot 4$ & 40 & 0.208 & $2 I$ & \\
\hline 22 & 1.0 & $3 \cdot 5$ & 40 & $0.22 \mathrm{I}$ & $2 I$ & \\
\hline 23 & I.O & 3.6 & 40 & $0.22 \mathrm{I}$ & $2 I$ & \\
\hline 24 & I.O & $3 \cdot 7$ & 40 & 0.222 & $2 I$ & \\
\hline 25 & 1.0 & 3.8 & 40 & 0.235 & I6 & \\
\hline 26 & I.O & 3.9 & 40 & 0.250 & 16 & \\
\hline 27 & 1.0 & 4.0 & 40 & 0.265 & 16 & \\
\hline 28 & 1.0 & $4 \cdot I$ & 40 & $0.28 \mathrm{I}$ & 16 & \\
\hline 29 & I.O & $4 \cdot 2$ & 40 & 0.294 & I6 & \\
\hline 30 & I.O & $4 \cdot 3$ & 40 & 0.306 & I6 & \\
\hline $3 I$ & $I . O$ & $4 \cdot 4$ & 40 & 0.32 .5 & 16 & \\
\hline 32 & I.O & $4 \cdot .5$ & 40 & 0.339 & I 6 & \\
\hline 33 & I. O & $4 \cdot 7$ & 40 & 0.377 & I 6 & \\
\hline .34 & I.O & $5 \cdot 3$ & $4 \%$ & 0.449 & 16 & \\
\hline 3.5 & I.O & 5.9 & 40 & 0.454 & I 6 & \\
\hline 36 & I. O & 6.5 & 40 & 0.459 & 16 & \\
\hline
\end{tabular}

In such a series the possible cases have been divided into three groups:

I. The solutions are identical in composition in different experiments, while the composition of the precipitates varies. The precipitate is a mixture of two phases.

2. The solutions differ in composition, but the precipitates have the same composition. The precipitate is a single chemical compound.

3. Both solutions and precipitates vary. The precipitate is a solid solution. 
In the above table we have four sets of bottles, Nos. I to 4,7 to Io, 22 to 24 and 34 to 36 , in each of which the composition of the solutions is identical and consequently the composition of the precipitates must differ on account of the varying proportions of the constituents used. Each of these sets then is in group I and contains two solid phases.

Nos. 5 and 6,16 to 21 and 25 to 33 have solutions of varying composition, but in each set analysis showed that the solid was of constant composition and each of these, therefore, contains a precipitate which is a chemical individual.

The precipitates were prepared for analysis by drying between filter paper and were then air-dried for a few hours, special care being used in the case of Nos. 25 to 33 to prevent the precipitate from absorbing carbon dioxide. The water was determined by heating at $100^{\circ}$, the barium by precipitation as barium sulphate and the solution of the salt was titrated with decinormal acid or with decinormal baryta water.

Analysis of Precipitate from Nos. 5 and 6.

Found:

$\mathrm{H}_{2} \mathrm{O}, 3.6 ; \mathrm{Ba}, 28.35 ;$ phthalic acid (by titration), 34. I.

Calculated for $\left(\mathrm{C}_{6} \mathrm{H}_{4} \mathrm{C}_{2} \mathrm{O}_{4}\right)_{2} \mathrm{H}_{2} \mathrm{BaH}_{2} \mathrm{O}: \mathrm{H}_{2} \mathrm{O}, 3.7 ; \mathrm{Ba}, 28.3$; phthalic acid (by titration), 34.2 Analysis of Precipitate from Nos. I6-2I.

Found: $\mathrm{H}_{2} \mathrm{O}, 6.64 ; \mathrm{Ba}, 42.25$.

Calculated for $\mathrm{C}_{6} \mathrm{H}_{4} \mathrm{C}_{2} \mathrm{O}_{4} \mathrm{Bar} .2 \mathrm{H}_{2} \mathrm{O}: \mathrm{H}_{2} \mathrm{O}, 6.68 ; \mathrm{Ba}, 42.4$.

In this case the dried salt was placed in a closed vessel over water, and absorbed an amount of water corresponding to the above loss of water when the original salt was dried.

Analysis of Precipitate from Nos. 25-33.

Found: $\mathrm{Ba}$ (total), $49.2 ; \mathrm{Ba}(\mathrm{OH})_{2}$, I0.9.

Calculated for $\left(\mathrm{C}_{6} \mathrm{H}_{4} \mathrm{C}_{2} \mathrm{O}_{4} \mathrm{Ba}\right)_{5} \mathrm{Ba}(\mathrm{OH})_{2}: \mathrm{Ba}$ (total), 49. $; \mathrm{Ba}(\mathrm{OH})_{2}$, ro.2.

As this precipitate did not dry well with filter paper there was an excess of barium hydroxide due to the evaporation of a small quantity of the solution.

The results of this series of experiments are expressed in the accompanying diagram. The ordinates give the acidity or alkalinity of the solutions and the abscissae the proportion of barium hydroxide to one phthalic acid in the system.

It would appear that if equilibrium were reached in Nos. I I to I3, they would be represented by the dotted line on the diagram, one part of which would represent bottles containing two solid phases and the other part bottles containing one solid phase, and this latter would be still another barium phthalate.

It was thought that the loss of phthalic acid on heating acid barium phthalate, mentioned by Hermann, might give a residue of constant composition. The acid phthalate does not lose any phthalic acid at 
$100^{\circ}$, but at $120^{\circ}$ loses weight slowly and after hours, gives a residue of constant composition, and if the temperature be raised to $140-150^{\circ}$, a residue of the same composition is obtained more rapidly.

Anulys of Residue Obtained, Etc.

Found:

Ba, 40.55; phthalic anhydride, 10.95 .

Calculated for $\left(\mathrm{C}_{6} \mathrm{H}_{4} \mathrm{C}_{2} \mathrm{O}_{4} \mathrm{Ba}\right)_{4} \mathrm{C}_{0} \mathrm{H}_{4} \mathrm{C}_{2} \mathrm{O}_{3}: \mathrm{Ba}, 40.6$; plithalie anhydride, II.2.

Owing to the small proportion of phthalic anhydrice in this salt and to its insolubility, the determination of phthalic anhydride could not be made very close.

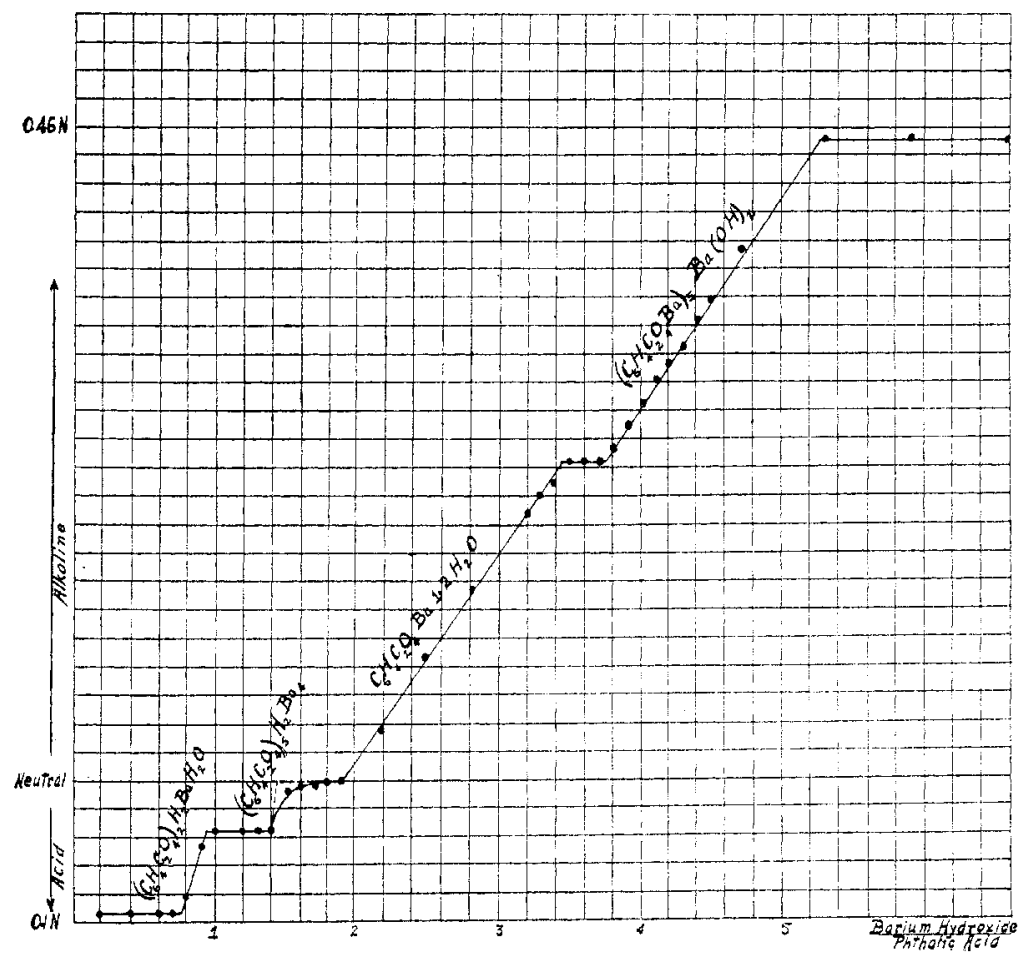

Analysis of the precipitates in Nos. I I and I 2 showed that they had approximately the same composition as the residue obtained by heating the acid barium phthalate and there would seem to be little doubt that if equilibrium were reached there would be obtained a salt of phthalic acid differing only from this in that it should be represented as containing phthalic acid instead of phthalic anhydride, thus $\left(\mathrm{C}_{6} \mathrm{H}_{4} \mathrm{C}_{2} \mathrm{O}_{4} \mathrm{Ba}\right)_{4} \mathrm{C}_{6} \mathrm{H}_{4} \mathrm{C}_{2} \mathrm{O}_{4} \mathrm{H}_{2}$ or $\left(\mathrm{C}_{6} \mathrm{H}_{4} \mathrm{C}_{2} \mathrm{O}_{4}\right)_{5} \mathrm{H}_{2} \mathrm{Ba}_{4}$.

It has been shown that in a system, the components of which are phthalic acid, barium hydroxide and water, four different barium phthalates may be obtained. Three of these have been isolated and 
lyzed, and conclusive evidence of the existence of the fourth has :n found and its probable formula has been given.

INIVERSITY OF TORONTO.

\section{A THIRD METHYL ESTER OF PHTHALIC ACID.}

By C. G. Allin.

Received July I2, I909.

These experiments were undertaken under the direction of Professor an with the object of finding out whether it was possible to prepare ester of phthalic acid corresponding to the barium salt $\left.\mathrm{H}_{4} \mathrm{C}_{2} \mathrm{O}_{4} \mathrm{Ba}\right)_{4} \mathrm{C}_{6} \mathrm{H}_{4} \mathrm{C}_{2} \mathrm{O}_{3}$. This barium salt was obtained by heating acid salt $\left(\mathrm{C}_{6} \mathrm{H}_{4} \mathrm{C}_{2} \mathrm{O}_{4}\right)_{2} \mathrm{H}_{2} \mathrm{BaH}_{2} \mathrm{O}$ at $\mathrm{I} 2 \mathrm{O}-\mathrm{I} 40^{\circ}$ until constant weight was ained.

3arium Salt and Ethyl Iodide.-(a) Five g. of the barium salt and $5 \mathrm{cc}$. yl iodide were shaken for several hours at room temperature.

b) Five $\mathrm{g}$. of the barium salt and $5 \mathrm{cc}$. ethyl iodide with $3 \mathrm{cc}$. ethyl alcowere shaken for several hours at room temperature.

c) Five $\mathrm{g}$. of the barium salt and $5 \mathrm{cc}$. ethyl iodide were heated at $100^{\circ}$ two hours.

The contents of each of these tubes were then treated with water and ted for barium iodide with negative results in each case. This indied that no ester had been formed.

3arium Salt and Methyl Sulphate.-(d) $0.5 \mathrm{~g}$. of the barium salt and c. methyl sulphate were shaken for four hours at room temperature. en the liquid was removed, the solid part was found to contain barium shate, which showed that a reaction had taken place.

e) Barium salt and methyl sulphate were heated in a sealed tube at - for four hours and then filtered. Part of the filtrate was shaken h water to decompose the methyl sulphate but all the oil disappeared, ester being saponified by the sulphuric acid from the methyl sulphate. ther part of the filtrate, on standing, separated into two layers, one which was found to contain much more sulphate than the other. The $t$ containing least sulphate was washed with water, dried over sulphuric 1 and saponified with potassium hydroxide solution.

0.1500 gram of the oil required, 12.1 $7 \mathrm{cc}$. potassium hydroxide sol.

Calculated for dimethyl phthalate, I6.13 cc.

Calculated for monomethyl phthalate, $18.59 \mathrm{cc}$.

$s$ showed that this oil was, at any rate, not the pure ester correspondto the barium salt, as the potassium hydroxide solution required to onify it would be intermediate between that required for the monohyl ester and that necessary for the dimethyl ester. Other experiits showed that when the neutral barium salt or the acid salt was 